\title{
The Washback Effect of Final Examinations at Payame Noor University on Teaching and Learning
}

\author{
Elahe Moradi \\ Payame Noor University of Tehran, Iran \\ moradi.pnum@gmail.com
}

Published online: 29 July 2019

To cite this article: Moradi E. 2019. The washback effect of final examinations at Payame Noor University on teaching and learning. Malaysian Journal of Distance Education 21(1): 17-42. https://doi.org/10.21315/mjde2019.21.1.2

To link to this article: https://doi.org/10.21315/mjde2019.21.1.2

\begin{abstract}
The notion of washback is a prominent concept in language teaching and testing. Examinations are considered to be powerful determiners of what goes on in classrooms and their results can play a significant role in setting educational standards of an institution. Moreover, awareness of the possible negative or positive consequences of certain modes of assessment can enhance teachers' as well as learners' level of self-direction in the process of language acquisition. The connection between testing, teaching and learning is addressed by a number of terms. Washback is one that refers to the influence of tests on teaching and learning. The aim of this study was to investigate whether the centralised final examinations in Payame Noor University (PNU), Iran's distance education university, have any washback effect on teaching and learning and if so what kind of washback it might take. After conducting a pilot study, data collection was done by using two questionnaires and an observation scheme. The data was analysed through descriptive statistics, Chi-square test, independent $t$-test, one-way ANOVA, and Pearson Correlation. The results indicated that PNU English and Foreign Languages (EFL) final examinations have washback effect on teaching and learning and this washback effect is more positive than negative. The study also investigated the factors that contribute to positive or negative effects including difficult aspects of teaching in distance education EFL and revealed that the effect of final examinations and the effect of such factors on teaching methodology is the same at this university.
\end{abstract}

Keywords: assessment, examinations, negative washback, positive washback, washback effect

(C) Penerbit Universiti Sains Malaysia, 2019. This work is licensed under the terms of the Creative Commons Attribution (CC BY) (http://creativecommons.org/licenses/by/4.0/). 


\section{Introduction}

Washback is a term widely used in language testing, yet it is rarely found in dictionaries. Washback, commonly used in the field of applied linguistics, refers to "the impact of a test on teaching" (Alderson and Wall, 1993:41; c.f. Alderson and Wall, 1993:117). It refers to the extent to which a test influences language teachers and learners to do things "they would not necessarily otherwise do because of the test" (Alderson and Wall, 1993:117). Biggs (1995:12) uses the term 'backwash' to refer to the fact that testing drives not only the curriculum, but also the teaching methods and students' approaches to learning (Crooks, 1988; Frederiksen and Collins, 1989).

Some writers use the term "washback", whereas others prefer "backwash" to describe the effects and influences of tests or examinations (Pan, 2009). According to Alderson and Wall (1993:115), the effect of testing on teaching is called "backwash" in general education and it has come to be known as "washback" in applied linguistics, though these terms are not different semantically or pragmatically. Pearson (1988:98) points out that "public examinations influence the attitudes, behaviors, and motivation of teachers, learners and parents, and because examinations often come at the end of a course, this influence is seen working in a backward direction, hence it is called washback." He further states that the direction in which washback actually operates should be forwards in time. Alderson and Wall (1993) emphasise that the introduction of tests can bear educational and attitudinal changes both on teachers and learners. They also believe that the introduction of tests create important educational consequences.

Prodromou (1993) points out that the washback issue has not been fully explored in second language research in spite of playing such a dominant role in classrooms. He believes that many assumptions about washback are simplistic and untested with little observation to back them up. This is confirmed by Alderson and Wall (1991) who have conducted comprehensive research into the area. They argue convincingly that washback is a more complex issue than simply the effect of testing on teaching. They believe that there is not an automatic relationship between tests and their impacts. Rather, specific areas such as teaching content and methodology, teacher competence, assessment methods and resources available need to be investigated as well as the extent of the impact and whether or not it is 
positive or negative. Their findings also include the potential effect of washback on the whole educational system.

Scholars have approached the washback issues from different perspectives (Luxia, 2005). Studies based on Cheng and Curtis (2004) and Luxia (2005), have shown that washback may have a positive or a negative or no influence on teaching and learning.

Washback is also described in the literature as overt or covert. According to Prodomou (1995:14), overt washback is usually negative and it has been seen when teachers use previous examination papers in class or when they emphasise those examples of the textbooks that are likely to be tested in the examinations. For this reason, teachers emphasise reading and writing more than speaking and listening. He sees the implicit consequences of covert washback as more of an underlying, unconscious process stemming from assumptions about how students learn. He likens it to "teaching a textbook as if it was a textbook" (1995:15).

Brindly (1998:52) talks of the dominating effect of assessment on teaching and learning to the point where assessments force teachers to teach to the test. Prodromou (1995:21) offers a solution for transforming negative washback into positive by shifting to a learner centered approach with an emphasis on the language process rather than "preoccupation with the endproduct". Examinations have washback effect on various aspects of the classrooms which can be categorised as curriculum, materials, teaching methods, feeling and attitudes, and learning (Spratt, 2008).

According to Bachman (1990), positive washback occurs when the assessment used the skills and content taught in the classroom. However, in many cases and particularly in high stakes testing, the curriculum is driven by the assessment leading to negative washback. Positive washback refers to expected test effects. For example, a test may encourage students to study more or may promote a connection between standards and instruction. Negative washback refers to the unexpected, harmful consequences of a test. For example, instruction may focus too heavily on test preparation at the expense of other activities. If there are no conflicts in the aims and activities of testing and teaching, testing supports teaching and then positive washback is assumed to happen. For example, when teaching is 
communicatively oriented, the use of direct testing tasks in national tests (e.g. interview or listening comprehension) supports communicative teaching and makes teachers, students and material providers move toward achieving communicative objectives, thereby it's producing positive washback.

Conversely, if a test objectives and activities are at variance with the objectives of the course, then there is likely to be negative washback. Wall (2005) mentioned that if the textbook and the examination had different content or aims, they might pull in different directions and negative washback might be created.

Some researchers imply that teachers' and students' attitudes towards the exams can create positive or negative washback. For example, Alderson and Hamp-Lyons (1996) mention how teacher attitudes towards the exams affect if and how teachers prepare their lessons and materials. Turner (2001) reports that when the teachers are involved in aspects of the test design process, their attitudes towards an exam become more positive and this promotes positive washback.

The format of the test can also make positive or negative washback effect. It is often asserted as by Hughes (2003) that direct, constructed response item formats will yield more positive washback.

There are various kinds of factors which play crucial roles in the way tests affect education (Alderson and Hamp-Lyons, 1996). What remains a question, however, is specifying the factors that have a potential to moderate the washback effects of test (Razavipour, Riazi and Rashidi, 2011).

\section{Methodology}

The purposes of this research were to map the field and to obtain an indepth understanding of the washback process integrated with a language assessment component. To conduct this study, the researcher used both qualitative and quantitative measures. 
The instruments used in the survey study were two questionnaires, one for Payame Noor University (PNU) professors and the other for PNU students. Both questionnaires explored the washback effect on aspects of teaching and learning through students' and professors' perceptions and attitudes.

To develop the items of the questionnaires, the researcher developed a questionnaire depending mostly on a similar questionnaire derived from a related study conducted by Cheng (2005) entitled "Changing language teaching through language testing." The items were adopted and adapted from the questionnaires of this book and the researcher modified some parts of the questionnaire in light of the objectives of the present study. For conducting the qualitative part of the study, 25 PNU English Translation Major classrooms were observed by the researcher. The researcher also designed a five-point Likert scale observation scheme to facilitate classroom observations with respect to the purpose of the study.

The population of this study consisted of 35 PNU professors and 200 male and female PNU students majoring in English Language Translation.

Having finished writing of the two questionnaires as a preliminary step; the researcher conducted a pilot study in order to validate both students' and professors' questionnaires which were going to be utilised in the main study. The computed Alpha Cronbach coefficients reliability for professors' and students' questionnaires were estimated to be 0.87 and 0.83 , respectively.

\section{Research Questions}

Specific questions this research aimed to answer were:

1. Do PNU final examinations have any washback effect on teaching and learning?

2. What kinds of washback do PNU final examinations have, positive or negative?

3. Do PNU final examinations have more impacts on teaching methodology than the other factors? 
22 Malaysian Journal of Distance Education 21(1), 17-42 (2019)

\section{Results and Discussion}

\section{Findings Related to the First Question}

Descriptive statistics of professors' questionnaire

Table A The effects of Payame Noor University final examinations on teaching

\begin{tabular}{lcccc}
\hline Item & Mean & SD & Chi-square & $p$-value \\
\hline 1. Teaching according to test formats & 3.31 & 1.38 & 0.257 & 0.612 \\
2. Adapting new teaching methods & 3.57 & 1.06 & 6.429 & $0.011^{*}$ \\
3. Implementing activities that may promote & 3.74 & 0.70 & 10.314 & 0.001 \\
$\quad \begin{array}{l}\text { students' test-taking skills } \\
\text { 4. Arranging class activities upon factors } \\
\text { other than objectives of the final exams }\end{array}$ & 3.65 & 1.13 & 3.457 & 0.063 \\
5. Teaching test-taking strategies & 3.11 & 0.96 & 1.400 & 0.237 \\
6. Using extra materials to help students & 3.17 & 1.29 & 0.029 & 0.866 \\
$\begin{array}{l}\text { succeed on the exams } \\
\text { 7. Displaying objectives of the final exams } \\
\text { throughout the course content }\end{array}$ & 3.68 & 0.96 & 3.457 & 0.063 \\
8. Giving students previous final exams in & 3.20 & 1.25 & 0.257 & 0.612 \\
$\quad \begin{array}{l}\text { order to familiarise them } \\
\text { 9. Covering every section of the textbooks }\end{array}$ & 3.71 & 1.17 & 6.429 & $0.011^{*}$ \\
10. Skipping over certain sections of the & 2.74 & 1.14 & 2.314 & 0.128 \\
$\quad$\begin{tabular}{l} 
textbooks \\
\hline
\end{tabular} & & & & \\
\hline
\end{tabular}

Item 3 (Table A) got the highest mean score. This indicates that most of the PNU professors try to promote students' test taking skills. Conversely, item 10 got the lowest mean score and it shows that PNU professors are not fond of skipping over certain sections of the textbooks because they are less likely to be tested on the final exams. 
Table B Other factors that affect teaching

\begin{tabular}{|c|c|c|c|c|c|}
\hline \multicolumn{2}{|c|}{ Item } & \multirow{2}{*}{$\begin{array}{c}\text { Mean } \\
2.54\end{array}$} & \multirow{2}{*}{$\frac{\mathrm{SD}}{1.14}$} & \multirow{2}{*}{$\begin{array}{c}\text { Chi-square } \\
8.257\end{array}$} & \multirow{2}{*}{$\frac{p \text {-value }}{0.004 *}$} \\
\hline 1. & $\begin{array}{l}\text { Spending less time on certain sections of } \\
\text { the textbooks because students are less } \\
\text { interested in them }\end{array}$ & & & & \\
\hline 2. & $\begin{array}{l}\text { Teaching whatever is important, no matter } \\
\text { whether students like it or not }\end{array}$ & 3.48 & 1.22 & 4.829 & $0.028^{*}$ \\
\hline 3. & $\begin{array}{l}\text { Teaching what will be tested because } \\
\text { students expected me to do so }\end{array}$ & 3.34 & 1.16 & 0.257 & 0.612 \\
\hline 4. & $\begin{array}{l}\text { Teaching tends to be influenced by } \\
\text { students' learning expectation and attitudes }\end{array}$ & 3.20 & 1.07 & 0.714 & 0.398 \\
\hline 5. & $\begin{array}{l}\text { Personality influences my selection of } \\
\text { teaching methods }\end{array}$ & 2.97 & 1.33 & 0.714 & 0.398 \\
\hline 6. & $\begin{array}{l}\text { University's policy influences my selection } \\
\text { of teaching methods }\end{array}$ & 3.31 & 1.07 & 0.257 & 0.612 \\
\hline
\end{tabular}

As it is evident, item 2 (Table B) got the highest mean score and it shows that most of the PNU professors teach whatever they think is important. Item 1 with the lowest mean score indicates that PNU professors don't spend less time on certain sections of the textbooks because their students are less interested in them.

Table C Most difficult aspects of teaching at Payame Noor University

\begin{tabular}{llccc}
\hline Item & Mean & SD & Chi-square & $p$-value \\
\hline 1. Students' current English level & 3.51 & 1.24 & 1.400 & 0.237 \\
2. Class size and the number of students & 3.17 & 1.22 & 0.029 & 0.866 \\
3. The lack of teaching and learning facilities & 3.62 & 0.94 & 1.400 & 0.237 \\
4. Too heavy workload & 3.82 & 1.20 & 3.457 & 0.063 \\
5. Limited number of sessions & 4.62 & 0.59 & 27.457 & $0.000^{*}$ \\
6. Inadequate textbooks and other teaching & 3.45 & 1.06 & 0.029 & 0.866 \\
$\quad \begin{array}{l}\text { resources } \\
\text { 7. Students' other engagements such as }\end{array}$ & 3.82 & 0.78 & & \\
$\quad$ & & & & \\
\hline
\end{tabular}


The results of Table $\mathrm{C}$ implies that among seven items of this part, the fifth item "limited number of sessions" got the highest mean score and this item is regarded as the main obstacle of teaching at PNU. Conversely, "students' other engagements such as employment and family" is the PNU professors' least concern.

Table D Ways of motivating PNU students in the context of PNU final examinations

\begin{tabular}{|c|c|c|c|c|}
\hline Item & Mean & SD & Chi-square & $p$-value \\
\hline $\begin{array}{l}\text { 1. Reviewing previous final examinations in } \\
\text { class }\end{array}$ & 3.20 & 1.05 & 0.257 & 0.612 \\
\hline 2. Using more authentic materials & 3.88 & 0.67 & 15.114 & $0.000 *$ \\
\hline $\begin{array}{l}\text { 3. Giving students more encouragement to } \\
\text { learn }\end{array}$ & 4.34 & 0.53 & 31.114 & $0.000^{*}$ \\
\hline 4. Creating positive attitude toward learning & 4.48 & 0.61 & 27.457 & $0.000 *$ \\
\hline $\begin{array}{l}\text { 5. Providing students with effective learning } \\
\text { strategies }\end{array}$ & 4.31 & 0.63 & 24.029 & $0.000 *$ \\
\hline
\end{tabular}

There are five items (Table D) under this category that ask PNU professors in what ways they would like to motivate their students to learn. The results of this table show that the great majority of the PNU professors incline to create positive attitude toward learning in order to motivate their students and they are less interested in reviewing previous final exams in class for motivating their students to study more.

Table E The basic functions of Payame Noor University final examinations

\begin{tabular}{llccc}
\hline Item & Mean & SD & Chi-square & $p$-value \\
\hline 1. To give feedback to teacher & 1.97 & 1.12 & 20.829 & $0.000^{*}$ \\
2. To assess students' learning difficulties & 2.14 & 0.94 & 20.829 & $0.000^{*}$ \\
3. To motivate students & 2.45 & 1.19 & 8.257 & $0.004^{*}$ \\
4. To direct students' learning & 2.80 & 1.13 & 3.457 & 0.063 \\
5. To identify area of re-teaching & 2.62 & 1.03 & 10.314 & $0.001^{*}$ \\
\hline
\end{tabular}

Nearly all PNU professors have negative attitude towards the function of the final examinations (Table E). Item 1 got the lowest mean score and it indicated that PNU final examinations have given very little feedback to the professors. 
Table F Learning strategies recommended by PNU professors in the context of PNU final examinations

\begin{tabular}{lrrrr}
\hline Item & Mean & SD & Chi-square & $p$-value \\
\hline 1. To learn to take better notes & 3.54 & 0.85 & 1.400 & 0.237 \\
2. To learn to express their opinions in the & 3.94 & 0.83 & 12.600 & $0.000^{*}$ \\
$\quad$ class & & & & \\
3. To learn to initiate question & 4.05 & 0.87 & 20.829 & $0.000^{*}$ \\
4. To study materials at home & 4.45 & 0.56 & 31.114 & $0.000^{*}$ \\
5. Not to memorise materials & 3.82 & 1.15 & 6.429 & $0.011^{*}$ \\
6. To review lessons often & 4.40 & 0.55 & 31.114 & $0.000^{*}$ \\
7. To learn with others & 4.22 & 0.68 & 17.857 & $0.000^{*}$ \\
8. To organise and to evaluate their learning & 4.45 & 0.65 & 24.029 & $0.000^{*}$ \\
9. To expose themselves to various English & 4.28 & 0.78 & 12.600 & $0.000^{*}$ \\
$\quad$ media & & & & \\
\hline
\end{tabular}

Nine strategies were listed (Table F) to explore PNU professors' attitudes towards the learning strategy they would recommend to their students in the context of PNU final examinations. The priority that PNU professors give to strategies they regard as important is revealed from the results. The results also show that these strategies are highly recommended by PNU professors as all mean scores are high.

"To study materials at home" and "To organise and to evaluate their learning" got the highest mean scores among all the other items and this indicates that these two strategies are recommended to PNU students more than other strategies.

Table G Teaching and learning material at Payame Noor University

\begin{tabular}{|c|c|c|c|c|}
\hline Item & Mean & SD & Chi-square & $p$-value \\
\hline 1. Textbooks & 4.71 & 0.458 & & \\
\hline $\begin{array}{l}\text { 2. Supplementary materials related to } \\
\text { objectives of the course }\end{array}$ & 2.97 & 1.12 & 4.829 & $0.028^{*}$ \\
\hline 3. Exam-related materials & 2.00 & 1.26 & 15.114 & $0.000^{*}$ \\
\hline
\end{tabular}


PNU professors were asked to express how often they used these three teaching and learning resources in their teaching. "Textbooks" was rated the most frequently used resource in teaching at PNU (Table G). This means that the majority of PNU professors use textbooks as the primary source of teaching content and they are less likely to use supplementary and examrelated materials in class.

Table H Teaching arrangement at Payame Noor University

\begin{tabular}{|c|c|c|c|c|}
\hline Item & Mean & SD & Chi-square & $p$-value \\
\hline 1. According to the textbook arrangement & 4.42 & 0.65 & 24.029 & $0.000^{*}$ \\
\hline $\begin{array}{l}\text { 2. According the content and materials to be } \\
\text { taught }\end{array}$ & 4.34 & 0.63 & 24.029 & $0.000^{*}$ \\
\hline $\begin{array}{l}\text { 3. According to what will be tested in the final } \\
\text { examinations }\end{array}$ & 3.60 & 1.14 & 0.714 & 0.398 \\
\hline
\end{tabular}

In this category, PNU professors were asked to show how they arrange their teaching at PNU. The results (Table $\mathrm{H}$ ) show that item 1 got the highest mean score and as it is evident, most of the PNU professors are teaching according to textbooks and they are less likely to teach according to what will be tested in the final examinations.

Descriptive statistics of students' questionnaire

Table 1 Students' perceptions of their professors' activities in class

\begin{tabular}{llcccc}
\hline & Mean & SD & Chi-square & $p$-value \\
\hline $\begin{array}{l}\text { 1. } \\
\begin{array}{l}\text { Making students familiar with the purpose } \\
\text { of the examinations }\end{array}\end{array}$ & 2.43 & 1.05 & 92.480 & $0.000^{*}$ \\
2. Trying to teach all parts of the textbooks & 2.68 & 1.09 & 52.020 & $0.000^{*}$ \\
3. Explaining objectives of the lesson & 3.04 & 0.96 & 26.182 & $0.000^{*}$ \\
4. Explaining previous final exams & 1.97 & 0.92 & 158.420 & $0.000^{*}$ \\
5. $\begin{array}{l}\text { Doing those exercises of the books that } \\
\text { are likely to be tested }\end{array}$ & 2.37 & 0.99 & 114.578 & $0.000^{*}$ \\
\hline
\end{tabular}

This category was designed to explore the students' perceptions of their professors' teaching activities in their classes. Students were asked to grade the frequency with which their professors organised the following activities in the class. As it is evident from the obtained mean scores (Table 1), 
item 3 got the highest mean score and this indicates that most of the PNU professors explain objectives of the lessons for their students and they are not fond of explaining previous final examinations for students to prepare them for the final exams.

Table 2 Students' perceptions of their professors' talking modes

\begin{tabular}{llcccc}
\hline & & Mean & SD & Chi-square & $p$-value \\
\hline 1. & Talk to the whole class & 3.96 & 1.04 & 54.080 & $0.000^{*}$ \\
2. & Talk to groups of students & 2.53 & 1.02 & 92.480 & $0.000^{*}$ \\
3. & Talk to individual students & 2.37 & 1.09 & 89.780 & $0.000^{*}$ \\
4. & Keep silent & 1.74 & 1.00 & 144.500 & $0.000^{*}$ \\
\hline
\end{tabular}

This category was designed to explore how much PNU professors talked in their classrooms according to PNU students (Table 2). PNU professors seem to talk to the whole class the most, followed respectively by talking to groups of students, individual students and keeping silent. This indicates that the PNU professors dominate and control the classroom talk for most of the time.

Table 3 Students' perceptions of their classroom activities

\begin{tabular}{|c|c|c|c|c|}
\hline & Mean & SD & Chi-square & $p$-value \\
\hline $\begin{array}{l}\text { 1. Doing previous final examinations in } \\
\text { class }\end{array}$ & 1.59 & 0.88 & 165.620 & $0.000^{*}$ \\
\hline 2. Doing discussion & 2.95 & 0.96 & 48.020 & $0.000^{*}$ \\
\hline $\begin{array}{l}\text { 3. Arguing for correct answers and correct } \\
\text { translations in class }\end{array}$ & 3.20 & 0.88 & 21.780 & $0.000^{*}$ \\
\hline 4. Expressing ideas & 3.19 & 0.94 & 19.220 & $0.000^{*}$ \\
\hline 5. Asking for clarification & 3.09 & 0.98 & 17.670 & $0.000^{*}$ \\
\hline
\end{tabular}

According to students' views, PNU final exams have impact on class activities and they lead students mostly to argue for correct answers, correct translations and to express their ideas in the class. Item 1 with the lowest mean score displays that PNU students rarely do previous final examinations in class (Table 3). 
Table 4 Students' preferred strategies regarding their final exams

\begin{tabular}{|c|c|c|c|c|}
\hline & Mean & SD & Chi-square & $p$-value \\
\hline 1. Taking notes & 3.21 & 1.17 & 1.620 & 0.203 \\
\hline 2. Studying materials at home & 3.57 & 1.13 & 27.380 & $0.000^{*}$ \\
\hline 3. Memorising materials & 3.51 & 1.11 & 13.520 & $0.000^{*}$ \\
\hline 4. Review lessons often & 3.83 & 0.89 & 44.180 & $0.000 *$ \\
\hline $\begin{array}{l}\text { 5. Preparing questions at home to ask in } \\
\text { class }\end{array}$ & 3.87 & 0.91 & 52.020 & $0.000^{*}$ \\
\hline 6. Organising and evaluating learning & 3.89 & 0.84 & 54.080 & $0.000^{*}$ \\
\hline 7. Learning with others & 3.56 & 1.24 & 6.480 & $0.011 *$ \\
\hline $\begin{array}{l}\text { 8. Listening to audio programs and } \\
\text { watching videos in English }\end{array}$ & 4.22 & 0.91 & 106.580 & $0.000^{*}$ \\
\hline
\end{tabular}

This category was designed to explore PNU students' preferred learning strategies, in order to understand whether or not PNU final examinations have an influence on students' learning strategies. There were eight items within this category (Table 4). The priority that students gave to strategies they regarded as important was revealed from the results. The most preferred strategy that PNU students use greatly is "listening to audio programs and watching videos in English" and the least preferred strategy is "taking notes".

Table 5 Students' attitudes towards the influence of aspects of the final exams

\begin{tabular}{llcccc}
\hline & & Mean & SD & Chi-square & $p$-value \\
\hline 1. & Motivation to learn & 3.36 & 1.19 & 5.780 & $0.016^{*}$ \\
2. Better teacher and student relationship & 3.40 & 1.09 & 1.280 & 0.258 \\
3. Anxiety and emotional tension & 3.47 & 1.12 & 6.480 & $0.011^{*}$ \\
4. & Future job opportunity & 3.34 & 1.09 & 0.500 & 0.480 \\
\hline
\end{tabular}

This category explores those aspects of students' lives that are affected by their final examination scores. The result from this category demonstrates that PNU students' scores have strong impact on these four items (Table 5). It can be seen that exam scores of PNU students mostly create anxiety and emotional tension. On the other hand, PNU students believe that their final exam scores have strong impact on their motivation to learn and on the student-teacher relationship. Also, PNU student indicate that their final 
examinations will have strong impact on their future job opportunity and this approves that PNU final examinations have macro washback effect in addition to micro washback effect.

Table 6 Students' attitudes towards the quality and format of their final exams

\begin{tabular}{|c|c|c|c|c|}
\hline & Mean & SD & Chi-square & $p$-value \\
\hline $\begin{array}{l}\text { 1. There is conformity between number of } \\
\text { question and determined time }\end{array}$ & 3.45 & 1.14 & 9.680 & $0.002 *$ \\
\hline $\begin{array}{l}\text { 2. There is conformity between exams and } \\
\text { objectives of the lesson }\end{array}$ & 3.08 & 1.05 & 1.280 & 0.258 \\
\hline $\begin{array}{l}\text { 3. There is conformity between exams and } \\
\text { content of textbooks }\end{array}$ & 3.61 & 0.95 & 30.420 & $0.000 *$ \\
\hline $\begin{array}{l}\text { 4. PNU students are satisfied with the ways of } \\
\text { testing of their oral courses }\end{array}$ & 2.69 & 1.22 & 21.780 & $0.000 *$ \\
\hline $\begin{array}{l}\text { 5. PNU students are satisfied with multiple- } \\
\text { choice exams }\end{array}$ & 3.89 & 1.07 & 46.080 & $0.000 *$ \\
\hline 6. PNU students are satisfied with essay exams & 2.57 & 1.14 & 30.420 & $0.000^{*}$ \\
\hline $\begin{array}{l}\text { 7. PNU students are satisfied with the exams that } \\
\text { have both multiple-choice and essay parts }\end{array}$ & 3.57 & 1.14 & 21.780 & $0.000 *$ \\
\hline
\end{tabular}

The aim of this category is to explore PNU students' attitudes towards the quality and format of their final exams. As it is evident (Table 6), item 5 with the highest mean score indicates that most of the PNU students are satisfied with the examinations in the multiple-choice format and item 6 with the lowest mean score displays that PNU students are dissatisfied with the examinations in essay format.

Table 7 Students' attitudes towards the effect of exams on themselves and on the process of learning

\begin{tabular}{llccc}
\hline & Mean & SD & Chi-square & p-value \\
\hline $\begin{array}{l}\text { 1. Students learning is improved by practicing } \\
\text { previous final examinations }\end{array}$ & 3.86 & 1.05 & 54.080 & $0.000^{*}$ \\
$\begin{array}{l}\text { 2. Taking examinations is a valuable learning } \\
\text { experience }\end{array}$ & 3.74 & 0.93 & 43.462 & $0.000^{*}$ \\
$\begin{array}{l}\text { 3. Examinations force students to study harder } \\
\text { Exa.8 }\end{array}$ & & & & \\
\hline
\end{tabular}


Table 7 (Continued)

\begin{tabular}{|c|c|c|c|c|}
\hline & Mean & SD & Chi-square & $\mathrm{p}$-value \\
\hline $\begin{array}{l}\text { 4. A student's score on an exam is a good } \\
\text { indication of how well she or he has } \\
\text { learned the material }\end{array}$ & 2.87 & 1.21 & 14.580 & $0.000 *$ \\
\hline $\begin{array}{l}\text { 5. Students perform better in an exam situation } \\
\text { than in normal teaching situation }\end{array}$ & 3.43 & 1.01 & 2.880 & 0.090 \\
\hline $\begin{array}{l}\text { 6. Examinations should not be used as a sole } \\
\text { determiner of student grades }\end{array}$ & 3.90 & 0.98 & 57.533 & $0.000 *$ \\
\hline $\begin{array}{l}\text { 7. Examination is one of the motivations for } \\
\text { students' learning }\end{array}$ & 3.89 & 0.96 & 69.620 & $0.000 *$ \\
\hline
\end{tabular}

This category was designed to explore the PNU students' attitudes towards their final examinations in relation to teaching and learning at PNU (Table 7). It is quite evident that PNU final examinations have strong impacts on students' attitudes towards themselves and their learning process. Among these items, item 4 got the lowest mean score and it shows that according to PNU students' views, examination scores are not good indications of how students have learned the materials and students don't consider the examinations as an accurate reflection of all aspects of their study. Conversely, item 6 got the highest mean score and it indicates that according to the PNU students' perception, examinations shouldn't be used as a sole determiner of student grades.

Table 8 The $t$-test for total items of the students' questionnaire

\begin{tabular}{ccccccc}
\hline & $N$ & Mean & SD & $t$-value & df & $p$-value \\
\hline Total students' responses & 192 & 3.229 & 0.289 & 10.998 & 191 & 0.000 \\
\hline
\end{tabular}

Table 9 The $t$-test for total items of the professors' questionnaire

\begin{tabular}{lcccccc}
\hline & $N$ & Mean & SD & $t$-value & df & $p$-value \\
\hline Total professors' responses & 35 & 3.659 & 0.225 & 17.342 & 34 & 0.000 \\
\hline
\end{tabular}

The above results (Table 8 ) show that the estimated means have a significant difference because the obtained $p$-values are so smaller than the significance level. ( $p$-value $=0.000<\alpha=0.05$ ), thus it can be concluded that PNU final examinations have significant washback effect on teaching and learning and the null hypothesis can be rejected. 


\section{Findings Related to the Second Question}

Question two of this study inquires about the type of washback (positive or negative) that PNU Translation Major final examinations may take. To answer this question, some of the items of the two questionnaires are regarded as positive and some of them as negative. Also, the washback effects of some items of these two questionnaires are unknown because no researcher could discover the exact type of their washback effect. For this reason, the researcher of this study doesn't consider any washback effect for such items.

Table 10 Professors' perception of positive and negative washback items

\begin{tabular}{llcccccc}
\hline Group & & $N$ & Mean & SD & $t$-value & df & $p$-value \\
\hline Response & Positive & 35 & 3.692 & 0.288 & 4.735 & 68 & 0.000 \\
& Negative & 35 & 3.213 & 0.525 & & & \\
\hline
\end{tabular}

Table 11 Students' perception of positive and negative washback items

\begin{tabular}{llcccccc}
\hline Group & & $N$ & Mean & SD & $t$-value & df & $p$-value \\
\hline Response & Positive & 195 & 3.329 & 0.335 & 7.422 & 392 & 0.000 \\
& Negative & 199 & 3.031 & 0.450 & & & \\
\hline
\end{tabular}

The above results (Table 10 and Table 11) show that the mean of those items with positive washback effect is larger than the mean of those items with negative washback effect. Thus, it can be concluded that the washback effect of PNU final examinations are more positive than negative.

\section{Findings Related to the Third Question}

The aim of the third question of the study is to investigate the effects of PNU final examinations and the effects of other factors in order to compare them to see which one has more impacts on teaching methodologies at PNU according to the PNU professors' views. 
Table 12 Comparing the effects of final examinations and the effects of other factors

\begin{tabular}{lcccc}
\hline Item & $\mathrm{M}$ & $\mathrm{SD}$ & $t$-value & $p$-value \\
\hline The effect of final examinations on teaching & 3.3914 & 0.40538 & -0.470 & 0.640 \\
$\begin{array}{l}\text { The effect of other factors and most difficult } \\
\text { aspects of teaching }\end{array}$ & 3.4327 & 0.32347 & -0.470 & 0.640 \\
\hline
\end{tabular}

As it is evident (Table 12), the estimated $p$-value is larger than the significance level (0.05). Thus, it can be inferred that the impact of these two items are the same and there is no significant difference between these items.

Table 13 Demographic information of the professors' questionnaire

\begin{tabular}{llcc}
\hline Item & Variable & Frequency & Percent \\
\hline Gender & Male & 22 & 62.9 \\
& Female & 13 & 37.1 \\
Age & $20-30$ & 7 & 20.0 \\
& $31-40$ & 15 & 42.9 \\
& $41-50$ & 6 & 17.1 \\
Academic qualification & Above 50 & 7 & 20.0 \\
& MA & 25 & 71.4 \\
Work experience in PNU & PhD & 10 & 28.6 \\
& $1-3$ & 17 & 48.6 \\
& $4-6$ & 8 & 22.9 \\
& $7-10$ & 4 & 11.4 \\
& Above 10 & 6 & 17.1 \\
\hline
\end{tabular}

For measuring the impact of demographic information on students' and professors' answers to the questionnaires, one-way ANOVA, $t$-test and Pearson correlation were estimated (Table 13 and Table 14) and finally the researchers came to these results:

1. there is no significant relationship between students' gender, the number of their current term, the medium of instruction of their professors in the class, and their answers to the items of the questionnaire.

2. there is no significant relationship between professors' gender, age, academic qualification, and their answers to the items of the questionnaire. But the results showed that the professors' work experience has had a significant effect on their answers to the questionnaires. 
Table 14 Demographic information of the students' questionnaire

\begin{tabular}{llcc}
\hline Item & Variable & Frequency & Percent \\
\hline Gender & Male & 50 & 25 \\
& Female & 150 & 75 \\
Number of & 2 & 37 & 18.8 \\
term & 3 & 29 & 14.7 \\
& 4 & 21 & 10.7 \\
& 5 & 13 & 6.6 \\
& 6 & 27 & 13.7 \\
& 7 & 16 & 8.1 \\
& 8 & 25 & 12.7 \\
& 9 & 16 & 8.1 \\
& 10 & 10 & 5.1 \\
& 12 & 3 & 1.5 \\
Medium of & English only & 12 & 6 \\
instruction & English supplemented with occasional Persian & 87 & 43.5 \\
& Half English and half Persian & 70 & 35 \\
& Mainly Persian & 31 & 15.5 \\
\hline
\end{tabular}

\section{Observation scheme}

To investigate the atmosphere of PNU Translation Major classrooms, 25 PNU classroom observations were carried out by the researcher. In order to facilitate observation of PNU classrooms, the researcher devised an observation scheme in a five-point Likert scale. This observation scheme was comprised of 10 main features and 32 items in total and it was adapted and adopted from the site: Cte.cornell.edu. The results of classroom observations were as follows (Table 15):

Table 15 Results of classroom observations

\begin{tabular}{llr}
\hline & Mean & SD \\
\hline Opening & & \\
$\begin{array}{l}\text { 1. Focuses student attention by (questions, etc.) before starting the } \\
\quad \text { lesson }\end{array}$ & 3 & 1.19 \\
2. States goals or objectives for the class & 3 & 1.19 \\
3. Starts slowly, allowing the class to warm up & 2.7 & 1.10 \\
\hline
\end{tabular}


Table 15 (Continued)

\begin{tabular}{lll}
\hline & Mean & SD \\
\hline Medium of instruction & & \\
4. English only & 1.7 & 0.48 \\
5. English supplemented with occasional Persian & 4.3 & 0.90 \\
6. Half English and half Persian & 3.1 & 1.19 \\
7. Mainly Persian & 2.3 & 0.75 \\
Pace & & \\
8. Seems about right & 3.1 & 1.24 \\
9. Seems too slow & 2.3 & 1.06 \\
10. Seems too fast & 2.6 & 1.32
\end{tabular}

\section{Classroom activities}

11. Students do discussion in the class

$2.1 \quad 0.93$

12. Students ask for clarification

$3.7 \quad 1.14$

13. Students argue for correct answers and translations

$3.0 \quad 1.14$

14. Students express their ideas

$2.9 \quad 1.13$

\section{Teacher talk}

15. Talk to the whole class

$4.6 \quad 0.87$

16. Talk to groups of students

$2.8 \quad 1.22$

17. Talk to individual students

$2.6 \quad 1.19$

18. Keep silent

$2.2 \quad 0.87$

\section{Class atmosphere}

19. Safe to speak

$4.3 \quad 0.48$

20. Safe to be wrong

$4.4 \quad 0.49$

21. Allow students to respond to one another

\section{Controversial issues}

22. Encourage students to interact directly by asking students to comment on each other's remarks

23. Encourage students to examine variety points of view before drawing conclusion

\section{Mechanics}

24. The teacher calls on non-volunteers as well as volunteers

$2.3 \quad 0.75$

25. The teacher invites alternative or additional answers

26. The teacher involves a large proportion of the class

$2.8 \quad 1.16$


Table 15 (Continued)

\begin{tabular}{llc}
\hline & Mean & SD \\
\hline $\begin{array}{l}\text { Reception of answers } \\
\text { 27. Accepts and acknowledges all answers by clarifying or }\end{array}$ & 2.6 & 1.00 \\
$\quad$ summarising & & \\
$\begin{array}{l}\text { 28. Praises answers } \\
\text { 29. Encourage students to evaluate their own or one another's }\end{array}$ & 3.1 & 1.29 \\
$\quad$ answers & & \\
Materials used in the class & & \\
30. textbooks & 4.8 & 0.44 \\
31. supplementary materials related to content of the books & 2.3 & 0.75 \\
32. exam-related materials & 2.2 & 0.55 \\
\hline
\end{tabular}

The results of the observation scheme indicate that PNU professors focus student attention before starting the lesson, and they state goals or objectives for the class sessions. The medium of instruction used by most of the PNU professors are English supplemented with occasional Persian and they talk to the whole class most of the time. The pace of the PNU classes seems about right. PNU students argue for correct answers and translations and they ask for clarification in the class as well. Moreover, students are safe to speak and safe to be wrong. As it is evident, their professors allow them to respond to one another and they are invited to have alternative or additional answers. PNU professors are likely to praise correct answers and encourage students to evaluate their own or another's answers. Apparently, the instructional materials used at PNU classrooms are textbooks and PNU professors rarely use supplementary or exam-related materials. They don't teach the content with an eye fixed on the previous final exams. The main aim of the PNU professors is not to make students ready for the final exams. They teach according to the textbooks and they don't spend their class time on teaching tips and tricks which turns the class to an exam-oriented one. It's very interesting that in spite of the existence of too many PNU examrelated publications in the market, most of the PNU professors are not fond of using them to prepare their students ready for the final examinations.

On the whole, the results of the observation showed that what has been observed at PNU classrooms has confirmed the findings of the study. 


\section{Conclusion}

In recent years, washback has become a very hot topic among many linguistic and educational experts, and many of them admit that washback does exist, and plays an important role in language teaching and learning. The notion of washback has been discussed for at least three decades in the field of language testing.

As pointed out by Glaser and Silver (1994:28), "there is good reason for the optimism that the oft-postponed wedding of assessment and instruction will occur." Teachers should be empowered to integrate assessment into efforts to improve teaching and learning and instruction. Washback tends to be a challenging phenomenon to research and measure. Washback needs to be planned, observed and studied. The review of recent washback studies shows that the number of such studies remains relatively small and they have been carried out in a restricted number of learning contexts and have employed a variety of research methods. The results of this study confirm the results of many other studies (e.g., Andrews, Fullilove and Wong, 2002; Alderson and Wall, 1993; Cheng and Curtis, 2004; McNamara, 2000) that found that the washback effect can influence learners.

There are four major washback studies. Alderson and Hamp-Lyons (1996) considered the effect of the Test of English as a Foreign Language (TOEFL) on teaching through utilising both interview and observation. The results of this study confirm the findings of Alderson and Hamp-Lyons because both of these studies indicated that exams affect what and how teachers teach.

In 1999, Cheng compared old and new versions of the Hong Kong Certificate of Education Examination (HKCEE). This study was conducted through students' and teachers' questionnaires, structural interviews and classroom observation. The results of this study are in line with the results of the study done by Cheng (1999). Both of these studies proved that examinations have influences on teaching methodology and classroom activities.

Shih (2007) investigated the impact of examinations on the learning process through interview and classroom observation. The results of the current study are in accord with the results of the study done by Shih and both of these studies investigated the washback effect from various perspectives. 
Shohamy et al. (1996) investigated the effect of testing on teaching and learning through two national tests in and beyond classroom setting. The instruments utilised in this study were consisted of students' questionnaire and interview with teachers. The result showed that these two tests had washback effect on teaching and learning. One of them had more positive washback and the other one created more negative washback effect. Therefore, the result of the current study supports the result of the study done by Shohamy et al.

The results obtained from this study based on professors' and students' questionnaires and direct observation of the PNU classrooms were as follows:

In terms of washback on aspects of teaching, it was clear that the final examinations influence some aspects of teaching at PNU. As was evident, negative washback emerges because PNU professors try to teach according to test format and they adapt new teaching methods based on the final exams. Moreover, they like to promote students' test-taking skills and strategies, and sometimes they try to give previous final exams to students in order to make them familiar with the exams. On the other hand, positive washback emerges because PNU professors base their classroom activities on objectives of the courses rather than on objectives of the final exams, which can increase positive washback. In terms of washback on aspects of learning, it became evident that PNU Translation Major final examinations have a great impact on learning strategies recommended by PNU professors to PNU students. It was apparent that in the context of PNU final examinations, PNU professors strongly recommend some useful strategies to enrich their students' learning. As the results of the study showed, in order to motivate students in the context of final examinations, PNU professors prefer to create positive attitude towards learning; give students more encouragement to learn; provide students with effective language learning strategies; and use more authentic materials in class. As the findings indicated, PNU professors are less likely to review previous final examinations in class when trying to motivate students to learn.

Summarising the findings concerning washback on teaching arrangement and materials used in class, it can be seen that PNU professors teach according to the textbooks and content and materials to be taught. As it was 
evident, they are less likely to teach according to what will be tested in the final examinations. As for teaching materials used at PNU classrooms, it was quite evident that PNU professors use textbooks mainly, and that they rarely use supplementary materials related to objectives of the courses and also they are less likely to use exam-related materials in class.

In the same way, in terms of students' perceptions of their professors' activities in class, it was clear that PNU professors' class activities create both positive and negative washback effects. As the results showed, positive washback is created because PNU professors explain objectives of the lessons for the students, they don't explain previous final examinations in class, and they don't emphasise those parts of the book that are likely to be tested in the final exams. On the other hand, negative washback emerges because students believe that their professors don't make them familiar with the purpose of the final examinations and they don't try to teach all parts of the textbooks.

Investigating washback on PNU students' activities in class revealed that PNU students don't do previous final examinations in class and concerning the results of the study, it can be concluded that PNU final examinations create positive washback on learning because they lead students to arguments for correct answers and translations in class, asking for clarification, and expressing ideas.

Summarising the findings of washback on aspects of learning, it can be seen that PNU Translation Major final examinations have impacts on learning strategies used by PNU students. It was quite evident that in the context of final examinations, PNU students use some useful learning strategies to enrich their learning. Additionally, the results showed that PNU students have positive attitudes towards their final examinations in the sense that they believe their final exams motivate them to learn and to have a better relationship with their professors. Moreover, students asserted that their final exams impact their future job opportunities, and it can be said that PNU final exams have macro washback effects in addition to micro washback effects. Because as Bachman (1990) and Bachman and Palmer (1996) believe, tests and test results have consequences beyond just the classroom. 
Tests have a significant impact on the career or life chances of individual test takers (e.g. employment opportunities). So the term "macro washback" or "impact" is generally used to describe these consequences of tests.

Regarding to students' attitudes towards the quality and format of the exams, it appears that PNU Translation Major final examinations are fair because there is conformity between the number of questions on the exams, and their determined time as well as between content and objectives of the textbooks and the final exams. Also, PNU students have positive attitudes towards the exams in the sense that they believe their final exams motivate them and force them to study harder and learn better. They regard taking exams as a valuable learning experience and believe students perform better in an exam situation than in a normal teaching situation. On the other hand, findings indicated that some PNU students have negative attitudes towards the exams because they don't consider exams as a sole determiner of grades and also, they believe that the score on an exam is not a good indication of how well a student learned the material.

On the whole, based on the findings of the professors' and students' questionnaires, it can be concluded that PNU Translation Major final examinations have washback effects on teaching methodology and learning at this university, and it is revealed that the created washback is more positive than negative.

Comparing the impact of final examinations on teaching methodology and the impact of other factors such as university policy, limited number of sessions, too heavy workload, lack of teaching and learning facilities and students' engagements like employment and family showed that both the final examinations and such factors have the same impact on teaching methodology at PNU.

\section{Implications of the Study}

Actually, washback tends to be a challenging phenomenon to research and measure. Below are some possible implications whose application can promote positive washback in PNU Translation Major final examinations. 
1. PNU final examinations should be developed in an unpredictable way. Because, whenever the content of a test becomes highly predictable, teaching and learning are likely to concentrate on what can be predicted.

2. PNU authorities should make professors and students aware of the purpose of examinations and the general format of tests to create positive washback effect.

3. PNU professors should collaborate with course designers and material providers to decide on every needed change such as new instructional strategies, revisions in the curricula, modified textbooks, professors' retraining, etc.

4. Professors' training is necessary. PNU professors need support and resources to function well in their field. Also, in-service training is essential so that professors can make decisions about what they should take from the examinations and what they should do in the classroom situations.

5. In order to increase positive washback effect of PNU final examinations, PNU professors' opinions should be taken into account during the planning stages. Also, it's important to communicate directly with students rather than to rely on their professors' views of what they think and feel.

\section{References}

Alderson, J. C. and L. Hamp-Lyons. 1996. TOEFL preparation courses: a study of washback. Language Testing 13(3): 280-279. https://doi.org/10.1177/026553229601300304 Alderson, J. C. and D. Wall. 1993. Does washback exist? Applied Linguistics 14: 115-129. https://doi.org/10.1093/applin/14.2.115

1991. The Sri Lankan O level evaluation project: third interim report. Lancaster: Lancaster University.

Andrews, S., J. Fullilove and Y. Wong. 2002. Targeting washback: a case-study. System 30: 207-223. https://doi.org/10.1016/S0346-251X(02)00005-2

Bachman, L. 1990. Fundamental considerations in language testing. Oxford: Oxford University Press.

Bachman, L. F. and A. S. Palmer. 1996. Language testing in practice: designing and developing useful language test. Oxford: Oxford University Press.

Biggs, J. B. 1995. Assumptions underlying new approaches to educational assessment. Curriculum Forum 4(2): 1-22. 
Brindly, G. 1998. Describing language development? In Interfaces between second language acquisition and language testing research, eds. L. F. Bachman and A. D. Cohen, 112-140. Cambridge: Cambridge University Press.

Cheng, L. 2005. Changing language teaching through language testing: A washback study. Cambridge: Cambridge University Press.

.1999. Changing assessment: washback on teacher perceptions and actions. Teaching and Teacher Education 15: 253-271. https://doi.org/10.1016/S0742051X(98)00046-8

Cheng, L. and A. Curtis. 2004. Washback or backwash: A review of the impact of testing on teaching and learning. In Washback in language testing: research contexts and methods, eds. L. Cheng, Y. Watanabe and A. Curtis, 3-18. Mahwah, NJ: Lawrence Erlbaum Associates.

Crooks, T. J. 1988. The impact of classroom evaluation practices on students. Review of Educational Research 58: 438-481. https://doi.org/10.3102/00346543058004438

Frederiksen, J. R. and A. Collins. 1989. A system approach to educational testing. Educational Researcher 18(9): 27-32. https://doi.org/10.3102/0013189X018009027

Glaser, R. and E. Silver. 1994. Assessment, testing, and instruction: retrospect and prospect (CSE Report 379). Los Angeles: University of California, Los Angeles, National Center for Research on Evaluation, Standards, and Student Testing (CRESST). https://doi.org/10.2307/1167389

Hughes, A. 2003. Testing for language teachers. 2nd ed. Cambridge: Cambridge University Press.

Luxia, Q. 2005. Stakeholders' conflicting aims undermine the washback function of a high-stake tests. Language Testing 22(2): 142-173. https://doi. org/101191/02655322051t300oa

McNamara, T. 2000. Language testing. Oxford: Oxford University Press.

Pan, Y. 2009. A review of washback and its pedagogical implications. VNU Journal of Science, Foreign Languages 25: 257-263. http://tpchi.vnu.edu.vn/nn_4_09/ b.8.pdf/

Pearson, I. 1988. Tests as levers for change. In ESP in the classroom: Practice and evaluation (ELT Documents 128), eds. D. Chamberlain and R. Baumgardner, 98-107. London: Modern English Publications.

Prodromou, L. 1995. The backwash effect: From testing to teaching. English Language Teaching Journal 49(1): 13-25. https://doi.org/10.1093/elt/49.1.13

1993. Teaching, testing and backwash in Greek ELT. http://testingforum.hau.gr/ docs/L.Prodromou-OK.pdf

Razavipour, K., A. Riazi and N. Rashidi. 2011. On the interaction of test washback and teacher assessment literacy: The case of Iranian EFL secondary school teachers. English Language Teaching 4(1): 156-161. https://doi.org/10.5539/elt.v4n1p156

Shih, C. 2007. A new washback model of students' learning. The Canadian Modern Language Review 64(1): 135-162. https://doi.org/10.3138/cmlr.64.1.135

Shohamy, E., S. Donitsa-Schmidt and I. Ferman. 1996. Test impact revisited: Washback effect over time. Language Testing 13(3): 298-317. https://doi. org/10.1177/026553229601300305 
42 Malaysian Journal of Distance Education 21(1), 17-42 (2019)

Spratt, M. 2008. Washback and the classroom: The implications for teaching and learning of studies of washback for exams, http://www.ltr.sagebub.com (accessed 18 November 2008).

Turner, R. H. 2001. Modes of social ascent through education: Sponsored and context mobility. In Education, Economy and Society, eds. A. H. Halsey, et al. New York: The Free Press of Glencoe.

Wall, D. 2005. The impact of high-stakes examinations on classroom teaching. Cambridge: Cambridge University Press. 